\title{
Akciğer kanser cerrahisinde onkolojik prensipler
}

\section{Oncological principles for the lung cancer surgery}

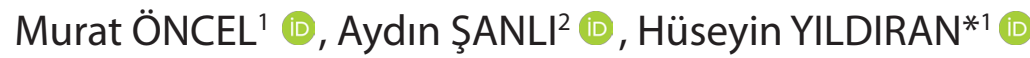

'Selçuk Üniversitesi Tıp Fakültesi Hastanesi, Göğüs Cerrahisi Anabilim Dalı, Konya/TÜRKiYE

${ }^{2}$ Dokuz Eylül Üniversitesi Tıp Fakültesi Hastanesi, Göğüs Cerrahisi Anabilim Dalı, İzmir/TÜRKiYE

\section{öz}

Küçük hücre dışı akciğer kanserlerinde cerrahi başarı, iyi bir anatomik rezeksiyon sonrası makroskobik ve mikroskobik olarak temiz gelen cerrahi sınır olması ve lenf nodlarında yayılım görülmemesidir. Cerrahi, akciğer kanserlerinde özellikle erken evrelerde en büyük tedavi şansını oluştururken tümör ve komşu dokuların birlikte anblok rezeksiyonları, cerrahi sınırda tümör dokusunun kalmayışı en uzun süreli sağkalımı sağlamaktadır. Küçük hücreli dışı akciğer kanserli hastaların yaklaşık \%70'inde kullanılan lobektomi standart bir anatomik rezeksiyondur. Uygulanan teknik pulmoner venlerin, arterin ve bronşun ayrı ayrı serbestleştirilmesi ve ardından mutlak bir şekilde hiler lenf nodları ve lenfatiklerin dikkatli diseksiyonudur. Akciğer rezeksiyonu geçirecek bütün hastalar için rezeksiyon öncesi evreleme; hastalığın seyri ve onkolojik girişimlerin algoritması için mutlaka yapılmalıdır.

Anahtar kelimeler: Akciğer kanseri; cerrahi metodlar; mediastinoskopi

\section{ABSTRACT}

In non-small cell lung cancer, after resection they must be not any spread of macroscopic and microscopic if you want anatomic success as a good clean surgical margins and lymph nodes .In lung cancer surgery, while providing the greatest chance of total cure, tumor which they were not invasion to surrounding tissue, especially along the anblok resection, it will provide the long term living because of the resection margin was staying the clear from the cancer mass. Lobectomy is being used approximately $70 \%$ of patients with non small cell when used as a standard anatomical resection, here in operative technique of the resection pulmonary veins, arteries and bronchi should carefully divised from other tissue. Then the individual division is the hilar lymph nodes and lymphatics were resected by careful dissections. All patients if the undergoing lung resection, they should be detected pre-staging progression entries with the algorithm.

Key words: Lung cancer; surgical methods; mediastinoscopy

Sorumlu yazar*: Hüseyin Yıldıran, Selçuk Üniversitesi Tıp Fakültesi Hastanesi, Göğüs Cerrahisi Anabilim Dalı, Konya/TÜRKIYE E-posta: h-yildiran@hotmail.com

ORCID: 0000-0003-0126-2531

Gönderim: 19/07/2018 kabul: 03/04/2020

Doi: $10.18663 /$ tjcl. 445743 


\section{Giriş}

Akciğer kanseri malignensiler arasında en önemli hastalıklardan bir tanesidir.

Dünyada erkeklerde en sık görülmekle birlikte, kadınlarda meme kanseri ve serviks kanserinden sonra 3. sırada görülmektedir. Mortalitede ise her iki cinste 1. sırada kanser türüdür. Akciğer kanserinin küçük hücreli akciğer kanseri ve küçük hücre dışı akciğer kanseri olmak üzere iki tipi vardır. Küçük hücre dışı akciğer kanserinde ise adenokarsinom, skuamöz hücreli karsinom ve büyük hücreli akciğer karsiomu olarak 3 ana subtipi görülmektedir. Etyolojide özellikle skuamoz hücreli tipinde en önemli etken sigaradır. Özellikle erken evrelerde tanı konduğu zaman rezeksiyon sonrası yaşam sürelerinde oldukça iyi sonuçlar alınmaktadır. Akciğer kanseri tedavisinde cerrahi, kemoterapi, radyoterapi tek tek veya kombine olarak uygulanmaktadır. Seçilecek tedavi şeklinin belirlenmesinde kanserin histopatolojik tipi, evrelemesi gibi parametreler çok önemlidir. Multidisipliner yaklaşımla cerrahi erken evrelerde altın standart olup lokal olarak ilerlemiş ve evresi artmış durumlarda da kemoterapi ve radyoterapi ile kombinasyon hastanın sağkalımını arttıracaktır. Derlememizde akciğer kanserinin özellikle küçük hücre dışı akciğer kanseri tipindeki yapılacak olan evrelemelerle cerrahi prensipler arasındaki ilişki ve destek tedavileri belirtilmiş olup küçük hücreli akciğer kanserinde cerrahi prensipler belirtilmiştir.

\section{Küçük Hücreli Dışı Akciğer Kanseri Cerrahisine Genel Bakış}

KHDAK (Küçük hücreli dışı akciğer kanseri) bilindiği üzere 3 ana tipe ayrılmaktadır. Skuamöz hücreli karsinom \%25, adenokarsinom \%40 ve büyük hücreli akciğer karsinomu \%15 oranında görülmektedir.[1] Bu kanserler küçük hücerli akciğer karsinomuna göre daha az invazif olup rezeksiyon için erken girişim yapma fırsatı vermektedirler. Genellikle cerrahi rezeksiyon Evre I, II ve IIIA da başarılı bir şekilde uygulanmaktadır.

[2] Evre III hastalığı olanlarda hastalığın seyri genellikle lokal yapılara invazyon ve mediastinal lenf nodu tutlumlarına bağlıdır. Evre III tümörlerde eğer tümör vena kava superior ve karinayı tutmuşsa rezeksiyon bazı durumlarda yapılabilir. Mediasten, kalp, damarlar ve birden fazla lenf nodu invazyonu olmuşsa rezeksiyon genellikle mümkün olmamaktadır.

KHDAK hastalarında yaklaşık \%70 olarak kullanılan lobektomi standart bir anatomik rezeksiyondur. Buradaki operatif teknik pulmoner venlerin, arterin ve bronşun ayrı ayrı bağlanması ve ardından mutlak bir şekilde hiler lenf nodları ve lenfatiklerin dikkatli diseksiyonudur. Pnömonektomi genellikle fissürden ayrılamayan, ana pulmoner arterin proksimal tutulumları, genişletilmiş rezeksiyonlarda ve yeterli pulmoner rezervi olanlarda kullanılan bir yöntemdir.[3] KHDAK tanısı alan ve erken evrede yakalanıp rezeksiyon kararı verilen sınırlı akciğer ve kalp rezervine sahip hastalarda tümör yükünü azaltmak için ender olarak yaklaşık \%5 civarında segmentektomi ve wedge rezeksiyonda kullanılmaktadır.

\section{Cerrahi Tanımlar}

Tümörün mediastinal organlara yayılması, patolojik plevral sıvı oluşturması, kardiak invazyon ve karşı tarafa yayılım ve lenf nodu metastazları sayılabilen birkaç inoperabilite kriterlerindendir.

KHDAK'de başarı iyi bir anatomik rezeksiyon sonrası makroskobik ve mikroskobik olarak temiz gelen cerrahi sınır ve lenf nodlarında yayılım görülmemesidir. Cerrahi, akciğer kanserlerinde en büyük tedavi şansını sağlarken özellikle tümör ve komşu dokuların birlikte anblok rezeksiyonları, cerrahi sınırda tümör dokusunun kalmayışı en uzun süreli sağkalımı sağlamaktadır. Bu anlayışlar ışığında yapılan çok merkezli çalışmalarda evre I hastalıkta 5 yıllık sağkalım \%74 olup evre II hastalıkta bu oran \%48 olarak bildirilmiştir.[3]

\section{Cerrahi Rezeksiyon Öncesi Değerlendirme}

Akciğer rezeksiyonu yapılacak bütün hastalar için rezeksiyon öncesi evreleme yapılmalıdır. Bu evrelemede lenf nodlarının tutulumu ve akciğer kitlesi üzerinde odaklanan tam bir anamnez ve fizik muayene ardından da komplet rezeksiyon için gerekli diagnostik incelemelerden BT ve PET taramaları yapılması uygundur. Yapılan çalışmalarda inkomplet rezeksiyonların yaşa ve sağkalıma olumlu katkısı yoktur.

\section{Geniş Rezeksiyon Endikasyonları}

KHDAK'de genellikle geniş rezeksiyonlarda morbidite ve mortalite artmaktadır. Kitlenin hilusu tutmuş olması, interlobar fissur tutulumu, daha önce yapılan operasyonda cerrahi sınırın pozitif olması ve çevre dokulara invaze özellikle büyük damar tutulumu, sağ intermediar bronş çevresinde konglomera tarzda invaze tümör oluşu operasyon esnasında geniş rezeksiyon yapma ihtimalini göstermektedir.[3,4]

\section{Sınırlı Rezeksiyon Gerektiren Olgular}

Akciğer rezeksiyon cerrahisinde cerrahı postoperatif dönemde sıkıntıya sokacak olan kalan akciğerin yeterli rezerve sahip olmamasıdır. Solunum fonksiyonlarının standart rezeksiyona izin vermediği olgularda zorunlu olarak yapılan sınırlı rezeksiyonlar akla gelmektedir. Bunlara daha çok "limited rezeksiyonlar" denmektedir. Genellikle sınırlı rezeksiyonlardan sonra lokal nüks tam rezeke edilenlere göre daha yüksek olmaktadır.[3] Kardiyopulmoner kapasitenin, üzerinde en fazla 
durulan ve sınırlı rezeksiyonu en kısa ve çabuk bir biçimde uygulanmasını gerektirecek bir durumdur.

Sınırı rezeksiyonların kanser cerrahisindeki yeri önümüzdeki yıllarda daha sık olarak tartışlacak ve muhtemelen erken yakalanmış tümörlerin tedavisinde minör rezeksiyonlar daha sık kullanılacaktır.[3] Bugün elimizde olan veriler T1 N0 tümörlerde sıyırma tekniği ile yapılan segmentektominin anatomik bir rezeksiyon olduğu ve solunum fonksiyonları yeterli olgularda oldukça etkili bir tedavi yöntemi olduğunu göstermektedir.[5,6]

\section{Rutin Mediastinoskopi Uygulaması}

1959 yılında ilk kez Carlens tarafından tanımlanan mediastinoskopi birçok çalışmaya konu olmuş güvenilir bir yöntem olup mortalitesi düşüktür. Hastaların uzun dönem sağkalım sürelerini etkileyen en önemli faktörlerden birisi de mediastinal lenf nodu tutulumudur. Preoperatif dönemde mediastinal lenf nodlarııın değerlendirilmesinde en sık kullanılan yöntem mediastinoskopidir. Diğer endikasyonları neoadjuvan tedavi sonrasında KHDAK 'nin yeniden evrelenmesi, orta mediastendeki kitlelerin patolojilerinin saptanması, kistik mediastinal kitlelerin tedavisi, etyolojisi tespit edilmemiş diffüz akciğer hastalığı varlığında veya akciğerde kitle olmaksızın tespit edilen mediastinal lenfadenopatilerin tanısının konulmasıdır.

Evre IIIA KHDAK hastalarında, N2 (aynı taraf paratrakeal lenf nodu) pozitifliğinde (üst mediastinal lenf nodu tutulumu yoksa) tam cerrahi rezeksiyon mümkün görünse de, bu hastalarda 5 yıllık sağkalım oranları \%10'un üzerine çıkamamaktadır.[6,7] Santral T1 ve T2 tümörlerde \%23, periferik T1 ve T2 tümörlerde ise $\% 11$ oranında mediastinal lenf nodu tutulumu bildirilmiştir. Bu oran Evre I - II tümörlerinde \%19 olarak bildirilmiştir.[8-10]

BT ile mediastinal lenf nodu değerlendirmesinde, lenf nodlarının 1 cm'den küçük olduğu olgularda \%7 oranında pozitif lenf nodu tutulumu gösterilmiştir. BT'nin sol taraf ve santral yerleşimli tümörlerde ve 7 numaralı istasyonu değerlendirmede doğruluk oranının en düşük düzeyde olduğu saptanmıştır. Dolayısıyla mediasten lenf bezi pozitifliğini değerlendirmede bilgisayarlı tomografi yetersiz kalmaktadır. Rezeksiyon sonrası mediastinal lenf nodu pozitif gelen olguların \%72'si BT ile negatif olduğu görülmüştür.[11]

\section{Aynı Taraf Paratrakeal Lenf Nodu Tutulumu (N2 hastalık)}

Patolojik olarak N2 pozitifliği tespit edilen hastalar aslında geniş bir yayılım oluşturur. Bu olgularda cerrahi tedavi sonrası 5 yıllık yaşama şansı çeşitli faktörlere bağlı olarak \%15 ile \%30 arasında değişmektedir.[12,13] Bu olgular içinde makroskopik olarak görülebilen lenf bezi metastazlı olgular bulunduğu gibi lenf bezlerinde mikrometastaz olan olgular da vardır. Çeşitli kaynaklarda klinik olarak N2 saptanan olgularda prognozun, N2 tanısı cerrahide konan olgulara göre daha kötü olduğu bildirilmiştir. KHDAK'nde opere edilenlerin \%45 inde tespit edilmiştir [6], bununla birlikte cerrahiden yararlanabilen N2 pozitif olanlar ise tüm KHDAK \%10'nu oluşturmaktadırlar. Tek olarak tutulum gösteren N2 pozitifliği, multipl seviyede N2 pozitifliği saptanan olgulara göre daha iyidir. Lenf bezinin büyük olması ekstrakapsüler yayılımın bir göstergesidir. $[14,15]$ Cerrahi uygulanan N2 pozitif olguların tek düzeyde ve ekstra kapsüler tutulumu olmayanlarda prognozun belirgin bir şekilde iyi olduğunu bildirmişlerdir. Patolojik N2 bulunan hastalarda sağkalım oranlarının yeterli olmaması ve primer hastalığın kemoterapiye daha iyi yanıt vermesi nedeniyle rezeksiyon önerilmemekte, dolayısıyla mediastinoskopi bu hastalarda gerekli görülmektedir.[7-13] Özellikle sol akciğer tümörlerinde "extended" mediastinoskopi (ECM) ve gerektiğinde video yardımlı torakoskopik cerrahi kullanılması, küçük hücreli operabıl hastalarda 5 ve 6 numaralı ganglionların değerlendirilmesi için önerilen yaklaşımlardır.[16-17]

\section{İyi Prognozlu N2 Pozitif Hastalık}

N2 hastalık saptanan olgularda iyi prognostik faktörler; komplet rezeksiyon, tek N2 varlığı, preoperatif patolojik N2 saptanmamış olması, metastazın intranodal olması, T1 veya T2 olması, subkarinal lenf nodu haricindeki lenf nodu istasyon pozitifliği olarak belirlenmiştir.[8,9,13,15] N2 hastalık olarak sınıflanan olgular aslında geniş bir spektrum oluşturur. Bu olgularda cerrahi tedavi sonrası 5 yıllık sağkalım çeşitli faktörlere bağlı olarak \% 19,2 ile \% 30 arasında değişmektedir. Çeşitli serilerde klinik olarak patolojik N2 saptanan olgularda prognozun, N2 tanısı cerrahi işlem sırasında konan olgulara göre daha kötü olduğu bildirilmiştir. Torakotomi sırasında N2 saptanması durumunda, perinodal yayılım yoksa multipl lenf nodu metastazı ve lenf nodu fikse değilse rezeksiyon yapılmaktadır. Komplet rezeke edilen T3N1 li olgular belirgin olarak N2 li olgulardan daha iyi sağ kalıma sahiptirler.[18] 4R,5,7 nolu istasyonların birinde kapsül invazyonu olmayan ve çevreye fiksasyon yapmayan N2 ler, yine N2 tutulumu inferior (7.8.ve 9. istasyonlar) ve süperior mediastinal kategori olarak ikiye ayrıldığı zaman ilk gruptaki sağ kalım diğeriyle karşılaştırmalı olarak daha sınırıdır.[10,16,18] Inferior ve süperior lokalizasyondaki N2 ler için sağ kalım oranını \%25'e karşın \%8 olarak belirtilmektedir. Komplet rezeke edilen T3N1 li olgular belirgin olarak N2 li olgulardan daha iyi sağkalıma sahiptirler.

\section{Kötü Prognozlu N2 Pozitif Hastalık}

Evrelemenin önemli ve en çok zorlanılan alanlarından birisi mediyastinal plevra içerisinde yer alan ve $\mathrm{N} 2$ olarak adlandırılan lenf nodlarına yayılımın değerlendirilmesidir. 
Patolojik N2'li akciğer kanserli olguların cerrahi tedavisi tartışmalıdır. N2 lenf nodu tutulumu ile primer cerrahiden fayda göremeyecek hastaların yapılan speysimenlerinde kötü prognozu lenf nodunda kapsül invazyonu, multipl istasyonlarda tutulum, en üst mediastinal seviyede N2.[1-2], T3 tümör ve histopatolojik tip (adenokarsinom) belirler.[10,17,19]

\section{Mediastinal Lenf Nodu Diseksiyonu}

Akciğer kanserinde sağkalımı etkileyen önemli faktörlerden biride lenfatik tutulumdur. Mediastinoskopi ile 1, 2R, 2L, 4R, 4L ve 7. istasyonlardan örnekleme yapılabilirken 5 ve 6 numara için genişletilmiş mediastinoskopi gerekmektedir.[20,21] Posterior yerleşimli subkarinal istasyonlara ulaşılmamaktadır. Son yıllarda video yardımlı torakoskopiler bu istasyonlara kolayca ulaşmaktadır. Mediastinoskopi evreleme ve neoadjuvan sonrası minör N2 hastalık tespitinde yararlıdır.

\section{Sağ Üst Mediastinal Diseksiyon}

Akciğer kanseri için komplet mediastinal lenf nodu disseksiyonu veya sistematik nodal diseksiyon gerekliliği üzerindeki tartışma diğer organ sistemleri tümörlerindeki lenf nodu diseksiyonunun (LND) gerekliliği ve etkinliği ile ilgili tartışmalara benzerdir. Tedavi edilebilir akciğer kanseri hastalarının cerrahi tedavisinde dünyaca kabul edilen görüş bölgesel lenf nodlarının sistematik nodal diseksiyon ile çıkarılması ve primer tümörün rezeksiyonudur.[22,23]

Apeksten karinaya kadar trakea ve VCS arası bölgedeki yağlı dokular anblok çıkarılır. Bunlar üst mediastinal (1 nolu lenf nodu), üst paratrakeal (2 nolu lenf nodu), preretro trakeal (3 nolu lenf nodu), alt paratrakeal (4R nolu lenf nodu), trakeobronşial köşe (10 nolu lenf nodu) lenf nodlarını çıkarılmasıdır.[24,25]

\section{Sağ Alt Mediastinal Diseksiyon}

Trakea orta hattının sağında; aorta kavsinin üst kenarından geçen doğrunun altında, üst lob bronşunun en üst kenarı hizasına kadar ana bronşu da kapsayan alanda yer alan ve mediastinal plevra içinde kalan lenf bezleridir. Karina seviyesinden pulmoner ligamana kadar perikard ve özefagus arası yağlı doku anblok rezeke edilir. Ayrıca subkarinal (7 nolu), paraözefagial (8 nolu) ve inferior pulmoner ligaman (9 nolu) alt lop rezeksiyonlarında mutlaka çıkartılmalıdır.[26,27]

\section{Sol Taraf Sistematik Mediastinal Diseksiyon}

Genellikle sol rezeksiyonlardan sonrada her kanser cerrahisinde olduğu gibi anblok lenf nodu diseksiyonu prognozu önemli ölçüde iyileştirmiştir. Böylelikle rezeksiyon tamamlandıktan sonra apeksten üst mediastinal plevra açılarak üst mediasten
( 1 nolu), üst paratrakeal ( 2 nolu) üst paratrakeal ( 2 nolu), preretrotrakeal ( 3 nolu), subaortik ( 5 nolu) ve paraaortik lenf bezleri anblok çıkarılması gerekir ki bu olay hastalığın seyrini yakından etkilemektedir. Tüm lenf nodu diseksiyonları çevre yağlı dokularla birlikte anblok çıkarılması gerekir, bu arada N.Vagus, N laringeus inferior ve N. frenikusun korunmasına ayrıca önem vermek gerekir.[28-30]

\section{Intraoperatif Yaklaşım}

Mediastinoskopi ile N2 pozitifliği gösterilmiş olmasına rağmen rezektabl olan ve iyi prognoz sağlanan hasta oranının, \% 3 - 6 olduğunu, bu iyi sağkalımı sağlayabilecek hastaların seçim kriterlerinin; kapsül invazyonunun olmayışı, 4, 5, 7 nolu istasyonlarda tek lenf nodu tutulumu ve fiksasyon bulunmayışı olduğu rapor edilmiştir.[31,32] Mediastinoskopi ile N2 saptanmayan hastalarda, sağ akciğer tümörlerinde rezektabilite oranı \% 95, sol akciğer tümörlerinde ise \% 73 tür. Bu hasta grubunda iyi sağkalım beklenir. Mediastinoskopi ile saptanamayan N2 pozitif hastalarda komplet rezeksiyon sonrası 5 yıllık sağkalımı \% 41, inkomplet rezeksiyon sonrası ise \%24 olarak bildirilmiştir. Mediastinoskopi negatifliği yalancı negatiflik bile olsa 5 yıllık sağkalım, \%30 - 45 oranında rapor edilmektedir. $[34,35]$ N2 ler içinde en iyi sağkalım, torakotomide diseksiyon sırasında ortaya çıkarılan N2 lerde elde edilir. Torakotomi sırasında N2 saptanması durumunda, nodun yayılımı yada fiksasyonu yoksa agresif rezeksiyon yapılmalıdır.

Ayrıca 4R, 5,7 nolu istasyonların herhangi birinde, intrakapsüler, tek N2'lere küratif rezeksiyonun hastalığın seyrini iyileştirdiği ortaya konmuştur.[36]

\section{Intraoperatif Teşhis ve Evreleme}

1997'de Goldstraw bir tanesi subkarinal, diğer ikisi lobun drenaj yolu üzerinde olması kaydıyla en az 3 adet lenf bezi disseksiyonu yapılması gerktiğini vurgulamıştır. Sağ üst ve orta lob için 2R, 4R, 7 nolu istasyonlar, sağ alt lob için 4R, 7, 8,9 nolu istasyonlar, sol üst lob için 5, 6, 7 nolu istasyonlar ve sol alt lob için 7, 8, 9 nolu istasyonların mutlaka örneklenmesi gerekmektedir.[37,38] Operasyon sırasında metastatik gibi görünmeyen lenf nodları bulunan hastaların \% 18'inde metastatik lenf nodları bulunduğunu saptamıştır. Ayrıca klinik olarak evre I olduğu düşünülen hastaların \% 68'inde intraoperatif dönemde N2 den şüphenilmiştir.[39] Bu nedenle intraoperatif değerlendirme sağkalım açısından akciğer kanseri cerrahisinde oldukça önemlidir. İntroperatif dönemde cerrahı yönlendirecek ve rezeksiyonun seyrini değiştirecek olan şüphesiz frozen patoloji ile yapılan doku tipi tayinidir. $[10,11,22,31]$ Bunlardan subplevral nodüller stapler ile yapılan 
eksizyonel biyopsilerdir. Tanı konulmadan pnömonektomi yapmak doğru değildir.

\section{Rezeksiyon Şekilleri}

\section{1-Lobektomi}

Akciğerin bir ya da sağda iki lobunun anatomik olarak rezeke edilmesidir. Lobektomi akciğer kanserinin tercih edilen cerrahi tedavi yöntemidir ve en uygun ameliyattır.

- Bilobektomi superior

Sağ üst lop anterior segment veya orta lopta yerleşen tümörlerde minör fissür inkomplet ise uygulanır.

- Bilobektomi inferior

Sağ alt lop ağzında veya alt lop superior segment ağzında yerleşen tümörlerde uygulanır.

\section{2-Segmentektomi}

Akciğerin bir ya da daha fazla segmentinin bronkovasküler yapılarının kesilerek anatomik çıkarılması olarak adlandırılır. Özellikle azalmış pulmoner rezervi olan primer akciğer kanserli, metastatik ya da benign hastalıkların tedavisinde tercih edilir. Segmentektomiden sonra lokal rekürrens oranının yüksek olması lobektomiyi tolere edebilen hastalara lobektominin tercih edilmesine yol açmıştır.[35,39]

\section{3-Sleeve Rezeksiyon}

Sleeve lobektomi pnömonektomiden kaçınarak sağlam akciğer dokusunu korumak amacı ile yapılan kalan bronş ile ana bronşun anastomoz edilmesinden oluşan bronkoplastik bir işlemdir. Sıklıkla sağ ve sol üst lop tümörlerde uygulanır. Pulmoner arter sleeve rezeksiyonu ile beraber uygulanabilir.

\section{4-Pnömonektomi}

Pnömonektomilerin en sıkyapılmanedenimalign hastalıklardır. Malign hastalıklarda pnömonektomi endikasyonlarl; santral tümör (ana pulmoner arterin veya venlerin proksimal tutulumu, geniş endobronşiyal tümör), fissür tutulumu, interlober lenf nodu ve ana bronşlar seviyesinde lenf nodu tutulumu olarak özetlenebilir.[28-33]

Pnömonektomilerde morbidite ve mortalite multifaktöriyeldir. Sağ pnomonektomilerde mortalite sola nazaran daha yüksek olup bronkoplevral fistül gelişimi sağda daha yüksektir. Özellikle akciğer kanseri olmak üzere, rezeksiyon gereken hastalarda ek hastalık bulunma oranı, hastaların yaşları ve benzer etiyolojileri nedeni ile yüksektir. Buna paralel olarak, rezeksiyon sonrası komplikasyon ve mortalite oranları yüksek olup, en sık görülenler kardiak veya pulmoner kökenlidir.[33,35]

\section{Evre I (T1N0-T2NO) Tedavi}

Evre IA ve IB tümörlerinin tedavisinde standart yaklaşım, cerrahi olarak tümörün ilgili akciğer dokusuyla beraber çıkartılması ve hiler, mediastinal lenf bezi diseksiyonu ile tam rezeksiyonudur. Tercih edilen rezeksiyon tipi lobektomidir, gerekirse daha geniş rezeksiyon yapılabilir. Pulmoner rezervi sınırlı olgularda, segmentektomi ve wedge rezeksiyon düşünülebilir.[31,32]

Hiler ve mediastinal lenf bezi diseksiyonu rutin olarak yapılmalıdır. Prospektif, randomize çalışmalarda, sistematik mediastinal lenf bezi örneklemesi ya da komplet mediastinal lenf bezi diseksiyonu arasında lokal nüks oranları ve yaşam süreleri açısından fark saptanmamıştır. Postoperatif torasik RT (radyoterapi) veya sistemik $\mathrm{KT}^{\prime}$ (kemoterapi) nin yaşam süresini uzattığı gösterilememiştir.[40,41] Bu amaçla tam olarak rezeke edilmiş evre I hastalıkta postoperatif torasik RT veya sistemik KT önerilmez. Tam olmayan rezeksiyonda (cerrahi sınır pozitifliğinde), olgunun kardiyopulmoner rezervleri uygunsa tamamlayıcı cerrahi, uygun değilse RT uygulanır. Medikal inoperabl olan ya da operasyonu kabul etmeyen olgularda torasik RT uygulanmalıdır. Yaşam beklentisi bu hastalarda \%94, 5 yıllık yaşam \%67 dir. Íkinci primer oluşma riski her yıl için \%2-3 tür, bu yıllardan sonra görülen tümörler yeni primer tümörlerdir.

\section{Evre II (T1N1-T2N1-T3N0) Tedavi}

Evre IIA ve IIB tümörlerinin tedavisinde standart yaklaşım, cerrahi olarak tümörün tam rezeksiyonudur. Operasyon, tam rezeksiyonu sağlayacak şekilde planlanmalı, uygun olgularda sleeve rezeksiyon pnömonektomiye tercih edilmelidir. Hiler ve mediastinal lenf bezi diseksiyonu rutin olarak yapılmalıdır. Hiler lenf bezi tutulumlarının periferik lenf bezi tutulumlarına göre daha düşük oranda sağkalımı olduğunu gösteren çalışmalar vardır.[42,43]

5 yıllık yaşam beklentisi

\section{T1N1区\%35-55}

\section{T2N1 ॠ\%25-44}

\section{T3NO 『\%25-30}

N faktörü mutlaka ortaya konmalıdır, T1N1-T2N1 İntraoperatif değerlendirme esnasında

Sağ üst lop tm+stump pozitif $\otimes$ Pnömenektomi

Sağ orta lop tm+stump pozitif $\otimes$ Sağ orta ve alt bilobektomi

Sağ alt lop tm+stump pozitif $\otimes$ sağ alt bilobektomi

Sol tm+stump pozitif $\otimes$ sol pnömonektomi yapılmalıdır. Tüm durumlar için sistematik mediastinal lenf nodu diseksiyonu gereklidir.[28-33,34] 


\section{Göğüs Duvarı Tutulumu (T3NO)}

Göğüs duvarı tutulumu olan rezektabl tümörlerde preoperatif radyoterapi operasyon esnasında daha az invazif işlem yapmayı gerektirmektedir. Bu tümörler genelde rezektabl olup,iki üst ve iki alt sağlam kaburga ile yanlardan $3-4 \mathrm{~cm}$ mesafe alarak rezeke edilmektedirler.[22-41] Sadece pariyetal plevra tutulu, kolayca endotorasik fasyadan ayrllıyor, ve frozen negatif ise göğüs duvarı rezeke edilmeyebilir. Tümörün adele ve kemik dokuları tuttuğu durumda anblok olarak rezeke edilmelidir. Ayrıca pariyetal plevra tutulumu göğüs duvarı tutulumu olarak kabul edilmelidir. Genellikle flail chest oluşması düşünülen geniş göğüs duvarı rezeksiyonlarında marlex ve metil metakrilat ile rekonstrüksiyon yapılmaktadır. Ameliyat mortalitesi \%4-10, 5 yıllık yaşam olasıllı̆ı \%29 dur.[33-38]

T3NO (Diafragma,perikard,mediastinal plevra ve vertebra tutulumu)

T3 olgularda preoperatif uzak metastaz araştırılmalı ve mediastinoskopi mutlaka yapılmalıdır. Mediastinoskopi ile olgularda ikinci istasyon N2'si, bulky N2 ve ekstranodal tutulum saptanırsa cerrahi yapılmaz ve kemoradyoterapi uygulanır.[1525] 5 yıllık yaşam beklentisi T3 NO için \%25-30, mortalite ise $\% 10$ dur. Plevral lavaj pozitifliğini değerlendirmek için VATS ile plevral lavaj alınmalıdır. Bu durumdaki hastalarda radikal pnömonektomi sistemik tam mediastinal diseksiyon gerekir. Diyafragma ve perikardın tutulu olduğu vakalarda diyafragma ve perikard çıkartılabilir, oluşan defekt sentetik greftle kapatılır. T3 N0 (Ana bronşa yerleşmiş karinaya $2 \mathrm{~cm}$ den yakın tümörler) Karinaya $2 \mathrm{~cm}$ den yakın ancak karinanın tutulmadığı tümörlerde 5 yıllık yaşam beklentisi \%12-46 dır.[31-37]Tümörün karinaya yakınlığı göz önüne alınarak pnömonektomi, sleeve lobektomi, karina sleeve rezeksiyonu uygulanabilir. Sistematik tam mediastinal diseksiyon tüm vakalarda olduğu gibi bu durumlarda da uygulanmaktadır. Operasyon esnasında bronş güdüğü enfekte olup fistül olmasın diye desteklenmelidir. Hastada eğer pozitif cerrahi sınır var ise T3N0-1 tümörlerde ve postoperatif multpl N1 ve N2 pozitifliği olanlarda rezeksiyon sonrası işaretleme yapılarak radyoterapi uygulanmalıdır.[12-23]

\section{Evre Illa (TxN2) Akciğer Kanserinde Tedavi}

Preoperatif mediasten değerlendirmesi (BT, mediastinoskopi, diğer nodal biyopsiler, PET BT) negatif olan, ancak torakotomi anında yapılan "frozen" çalışmalarında N2 saptanan olgularda; tam rezeksiyon sağlanabilecekse operasyona devam edilir. Tam rezeke edilen olgular, lokal nüks riskini azaltmak amacıyla postoperatif torasik RT programına alınırlar. Tam rezeksiyon mümkün değilse veya ekstrakapsüler nodal hastalık , "bulky" veya çok istasyonlu nodal hastalık varsa planlanan rezeksiyona devam edilmemelidir.[13,14-24] N2 olgularda neoadjuvan KT sonrası "down stage" gözlenirse cerrahi uygulanması yönünde görüş birliği vardır. Neoadjuvan kemoterapi uygulanmasının tümör boyutunda gerileme, radikal rezeksiyon şansının artırıması, tespit edilemeyen metastazların giderilmesi gibi faydaları olmaktadır,[44] "Down stage" olmayan olgularda cerrahinin yeri tartışmalıdır ve pnömonektomi gerektiren olgularda yüksek mortalite riski nedeniyle cerrahiden kaçınılmalıdır. Bulky N2'si olan olgularda uygun tedavi seçeneği kemoradyoterapidir.

Tam rezeke olgularda postoperatif torasik RT lokal nüks riskini azaltmak amacıyla uygulanmalıdır. Neoadjuvant kemoterapiye yanıt alınmış ve opere olmuş olgularda aynı protokole adjuvant olarak 2-3 kür daha devam edilmelidir.

\section{Evre IIIlb Akciğer Kanserinde Tedavi}

Rezeksiyon potansiyeli olan T4 N0-1 M0 olgularda (süperior vena kava, sol atrium, vertebra cismi, ana karina, distal pulmoner arterin minimal tutulduğu seçilmiş olgular) 2-3 kür sisplatin bazlı sistemik indüksiyon KT'si uygulandıktan sonra, primer tümörde küçülme varsa cerrahi tedavi yönünden tekrar değerlendirilir. Stabil ya da progresyon varsa, radikal torasik RT veya eş zamanlı kemoradyoterapi programına alınır. Cerrahi için uygun olmayan performans durumu, Evre IIIA ve IIIB olgularda ardışık ya da eş zamanlı kemoradyoterapi uygulanır. [14,15,18-21] KT + RT kombine modellerde sisplatin bazlı kombinasyon rejimleri kullanılmalıdır. Bu hastalarda sıklıkla mediastinum, kalp ,büyük damarlar, vertebra cisim tutulumu, malign plevral effüzyon görülebilir.

\section{Özel Durumlarda Cerrahi Yaklaşım}

Superior sulkus tümörlerinin tedavisi farklılık gösterir. Superior sulkus tümörleri cerrahi öncesi eşzamanlı kemoradyoterapi veya kemoterapi alamayacaksa sadece radyoterapi almalıdır. Kemoradyoterapi sonrası cerrahi uygulanması tercih edilmelidir.[20-34]

Bu hastalarda mutlaka preoperatif olarak BT ve MRI çekilmelidir. Doku tanısı olmadan cerrahi tedavi girişimi başlanmamalıdır. [21-36] Superior sulkusta rezektabl tümörü (T3-4, N0-1) olan ve önce opere edilen hastalar için, cerrahi rezeksiyondan sonra eşzamanlı kemoradyoterapi yapılabilir. Superior sulkus tümörlerinde, cerrahi ve postoperatif radyoterapi \pm eşzamanlı kemoterapi ile tedavi edilen hastalar arasında, 5 yıllık genel sağkalım oranı yaklaşık olarak $\% 40$ olmuştur. 
Superior sulkus tümörlerinde cerrahi kontrendikasyonlar şu şekilde özetlenebilir:

1. Brakial pleksus C7-T1'in üstü ve paraspinal bölgenin (özellikle intervertebral foramina) tutulumu, laringeal sinir tutulumu ve vertebra gövdesinin yaygın olarak tutulumu.

2. Mediastinal lenf nodu tutulumu

3. Boyun tabanında yumuşak dokuların tutulumu.

4. Vena kava superior sendromu (VCSS) veya büyük ven tutulumu (subklavian ven veya brakiosefalik ven).

5. Uzak metastaz olması.

6. Klinik olarak önemli kardiyopulmoner hastalık.

7. Subklavian arterin tutulumu rölatif kontrendikasyondur. Asıl olarak subklavian ven tutulumu daha ciddi kontrendikasyondur.

\section{Senkron Primer Akciğer Kanseri}

Farklı lob veya akciğerde eş zamanlı iki pulmoner nodülün varlığında metastaz ile primer senkron akciğer kanseri ayrımını yapmak zordur. Akciğerde eşzamanlı ve farklı lobda multipl kitle saptandığı zaman ilk planda akciğere metastaz yapan maligniteler yönünden, ekstrapulmoner primer odak taraması yapılmaktadır. Erken evrelerde cerrahi planlanmalıdır. Senkron tümörlerde en sık rastlanan hücre tipi skuamoz hücreli karsinomdur.[30-37] Eğer lezyonlar aynı tarafta ise torakotomi yeterlidir. Farklı hemitoraksta ise ve pulmoner fonksiyonları yeterli ise medyan sternotomi ile aynı seansta rezeksiyon uygulanabilir. Ipsilateral senkron kanserli hastalarda iki lezyon bilobektomi, pnömonektomi, multipl wedge rezeksiyonlar veya lobektomi ve wedge rezeksiyon ile çıkarılabilir. Hastalığın evresi, evresi en yüksek olan tümörle ifade edilmektedir.

\section{Multipl Primer Akciğer Kanseri}

Akciğer kanserli hastaların \% 6'sını multipl primer akciğer kanserleri oluşturmaktadır. Bunların da \% 30'u senkron kanserlerdir. Bu kanserlerin gerçek sıklıklarını saptamak zordur. Akciğer kanserli bir hastanın izleminde ortaya çıkan yeni bir kanserin (metakron) sıklığı her yıl için \% 0.5- 4 arasında bir değerdedir ve bu rakam ortalama \% 1,6'dır. İkinci bir primer kanserin ilk 5 yıl içinde görülme sıklığı \% 1, sonraki 5 yıl içinde ise $\% 2$ ve daha fazla olarak bildirilmiştir. Senkron akciğer kanserleri sıklıkla torakotomi sırasında tanı konan kanserlerdir. Senkron tümörlerin üçte ikisi aynı tarafta ortaya çıkmaktadır. Aynı histolojik yapıda olduğunda bunun senkronöz tümör olup olmadığı tartışmaları olmakla beraber, bu konuda bazı çelişkiler vardır. Aynı lobda olduğunda bunun satellit tümör olma olasılığı vardır. Erken evre akciğer kanserlerinde görülme sıklığı daha fazladır ve 5 yıllık sağkalım daha azdır. Metakron akciğer kanserlerinde iki kanser arasındaki süre 18 ile 79 ay arasında değişmektedir ve ortalama 48 ay olarak bulunmuştur. Metakron tümörlerin yarısından daha azı orijinal akciğer kanseriyle aynı tarafta gelişir. Büyük çoğunluğu ilk tanı konan akciğer kanseriyle aynı histolojiye sahiptir. Olguların üçte ikisi skuamöz hücreli kanserdir. Hastaların büyük kısmı rezeke edilebilir, ancak yetersiz pulmoner kapasite nedeniyle sağkalım uzun olmamaktadır.

\section{Küçük Hücreli Akciğer Kanserlerinde Cerrahi Tedavi}

Genel olarak evre I ve evre I| hastalığı olan hastalar icin cerrahi; kür elde etmede en iyi şanstır. Cerrahi prosedür, hastalığın yaygınlığı ve hastanın kardiyopulmoner rezervine göre belirlenir. Anatomik olarak uygunsa ve negatif sınır elde edilebilecek rezeksiyon uygulanabilecekse akciğer koruyucu anatomik rezeksiyon (sleeve lobektomi) pnömonektomiye tercih edilmektedir.[22-41,45] Aksi takdirde fizyolojik olarak mümkünse lobektomi veya pnömonektomi yapılabilir. Segmentektomi veya wedge rezeksiyon gibi akciğer koruyucu cerrahilerin ciddi ölçüde azalmış pulmoner fonksiyonu olan ve başka türlü cerrahi adayı olamayan hastalarda yararlı olup olmadığı tartışmalıdır. Eğer bir torasik cerrah tarafından evre I ve II hastalar medikal inoperabl kabul edilirse, bu hastalar potansiyel olarak küratif tedavi almak durumundadır. Ayrıca preoperatif evre 1 (periferik T1-2NO M0) tümörlerde cerrahi rezeksiyon, mediastinal lenf nodu diseksiyonu ve aynı zamanda adjuvan terapi gerekmektedir.[22-41,45] Operasyon sırasında tanı konan vakalarda NO ise rezeksiyon, sistemik mediastinal diseksiyonu ve adjuvan tedavi; N1 pozistif ise cerrahi rezeksiyon sonrası sistemik mediastinal lenf nodu diseksiyonu ve ardından adjuvan kimyasal tedavi gerekmektedir. N2 pozitif multipl istasyon tutulumunda inoperabl kabul edilmektedir.

\section{Sonuç}

Dünyada giderek ciddi bir sağlık sorunu olan akciğer kanserinin tip ve evrelemenin doğru bir şekilde bilinmesinin bu hastalığa karşı önlemlerin alınmasında ve geleceğe yönelik tedavi planlamalarının yapılabilmesinde yararlı olacağına inanmaktayız. Ayrıca şu da çok önemli bir gerçek ki iyi bir cerrah evreleme ile hangi noktada duracağını bilmeli ve hastanın progresini ve hangi tedavinin ona yarar vereceğini multidisipliner bir yaklaşımla göğüs hastalıkları uzmanları, radyoloji uzmanları, nükleer tıp uzmanları ve patologlarla istişare ederek karar vermelidirler. 


\section{Kaynaklar}

1. Ding N, Zhou N, Zhou M, et al. Respiratory cancers and pollution. Eur Rev Med Pharmacol Sci. 2015 Jan;19(1):31-7.

2. Rosell R. A randomise trial comparing preoperative chemotherapy plus surgery with surgery alone in patients NSCLC. N Engl J Med 1994;330:153-8.

3. Roth J. A randomise trial comparing preoperative chemotherapy and surgery alone in resectable stage III A NSCLC J Natl Cancer Inst 1994;86.673-80.

4. Vansteenkiste JF. Present status of induction treatment for N2 NSCLC: A review. Eur J Cardiothorac Surg 1998;13.1-12.

5. Koizumi K, Haragushi S Surgical treatment of lung cancer with vertebral invasion Ann Thorac Cardiovasc Surgy 2004 Aug;10(4):229-34.

6. Grunenwald D. H. Mazel C. Radical en bloc resection invading the spine. J Thorac Cardiovasc Surg 2002;123:271- 80.

7. Lucchi M, Viti A, Melfi F et al. III B- T4 NSCLC: Indications and results of surgical treatment. J Card Surg 2007 Jun;48(3):369-74.

8. AF Ravens. Mediastinal LN involvement in potentially resectable lung cancer: comparison of CT,PET and EUS wiht and wihtout fine needle aspiration. Chest 2003;123:442-51.

9. Grunenwald DH, Albain KS. The potential role of surgery after induction treatment. Semin Radiat Oncol. 2004 Oct;14(4):335-9.

10. Melfi F, Fanucchi O, Davini F, et al. Ten-year experience of mediastinal robotic surgery in a single referral centre. Eur J Cardiothorac Surg. 2012 Apr;41(4):847-51.

11. Sonett JR, Suntharalingam M, Edelman MJ, et al. Pulmonary resection after curative intent radiotherapy (>59 Gy) and concurrent chemotherapy in non-small-cell lung cancer. Ann Thorac Surg. 2004 Oct;78(4):1200-5.

12. Daly BD, Fernando HC, Ketchedjian A, et al. Pneumonectomy after high-dose radiation and concurrent chemotherapy for nonsmall cell lung cancer. Ann Thorac Surg. 2006 Jul;82(1):227-31.

13. Fowler WC, Langer CJ, Curran WJ Jr, et al. Postoperative complications after combined neoadjuvant treatment of lung cancer. Ann Thorac Surg. 1993 Apr;55(4):986-9.

14. Dassanayake DL, Muthunayake TM, Senevirathna KH, et al. Staging of lung cancer in a tertiary care setting in Sri Lanka, using TNM 7th edition. A comparison against TNM6. BMC Res Notes. 2012 Mar 14;5.143.

15. Chien CR, Yang ST, Chen CY, et al. Impact of the new lung cancer staging system for a predominantly advanced-disease patient population. J Thorac Oncol. 2010 Mar;5(3):340-3.
16. Shepherd FA, Crowley J, Van Houtte $P$, et al; International Association for the Study of Lung Cancer International Staging Committee and Participating Institutions. The International Association for the Study of Lung Cancer lung cancer staging project: proposals regarding the clinical staging of small cell lung cancer in the forthcoming (seventh) edition of the tumor, node, metastasis classification for lung cancer. J Thorac Oncol. 2007 Dec;2(12):1067-77.

17. Giroux DJ, Rami-Porta R, Chansky K, et al, International Association for the Study of Lung Cancer International Staging Committee. The IASLC Lung Cancer Staging Project: data elements for the prospective project. J Thorac Oncol. 2009 Jun;4(6):679-83.

18. Jones KD. An update on lung cancer staging. Adv Anat Pathol. 2010 Jan;17(1):33-7.

19. Yoshida J, Nagai K, Asamura H, et al. Japanese Joint Committee for Lung Cancer Registration. Visceral pleura invasion impact on non-small cell lung cancer patient survival: its implications for the forthcoming TNM staging based on a large-scale nationwide database. J Thorac Oncol. 2009 Aug;4(8):959-63.

20. Leuzzi G, Cesario A, Cafarotti S, et al. Surgical Treatment in Patient with Non-Small-Cell Lung Cancer with Fissure Involvement: Anatomical versus Nonanatomical Resection. JThorac Oncol. 2013 Nov 19.

21. Ma Q, Liu D, Guo Y, et al. Surgical therapeutic strategy for nonsmall cell lung cancer with mediastinal lymph node metastasis (N2). Zhongguo Fei Ai Za Zhi. 2010 Apr;13(4):342-8.

22. Shields TW. Surgery of small cell lung cancer. Chest. 1986 Apr;89(4 Suppl):264S-267S. Review.

23. Charloux A, Quoix E, Wolkove N. The increasing incidence of lung adenocarcinoma, reality or artifact? A review of the epidemiology of lung adenocarcinoma. Int J Epidemiol 1997;26:14-23.

24. El-Torky M, El-Zeky F, Hall JC. Significant changes in the distribution of histologic types of lung cancer. Cancer 1990;65:2361-7.

25. Morabia A, Wynder EL. Cigarette smoking and lung cancer cell types. Cancer 1991;68:2074-8.

26. Wynder EL, Hoffmann D. Smoking and lung cancer, scientific challenges and opportunities. Cancer Res 1994;54:5284-95.

27. Jöckel KH, Ahrens W, Jahn I. Occupational risk factors for lung cancer, a case control study in West Germany. Int J Epidemiol 1998;27:549-60.

28. Mooi WJ. Common lung cancers. Hasleton PS (ed). Spencer's Pathology of the lung. NewYork, Mc Graw Hill, 1996;100-9. 
29. Halilçolar H, Tatar D, Ertuğrul G, et al. Epidemiyoloji. In: Çavdar T, Ekim N, Akkoçlu A, Öztürk C eds. Akciğer kanseri multidisipliner yaklaşım. 1.Baskı. Ankara: Bilimsel Tıp Yayınevi;1999:17-22.

30. Levi F, Franceschi S, Vecchia C. Lung carcinoma trends by histologic type in Vaud and Neuchatel, Switzerland, 1974-1994. Cancer 1997;79:906-14.

31. Ernster VL, Mustachhi P, Osann KE. Epidemiology of lung cancer . In: Textbook of Respiratory Medicine. Murray JF, Nadel JA (eds). 2nd edition. Philedelphia W.B. Saunders Co. 1994;1504-27.

32. Zheng T, Holford TR, Boyle P. Time trend and the age-periodcohort effect on the incidence of histologic types of lung cancer in Connecticut, 1960-1989. Cancer 1994;74:1556-67.

33. Boffa DJ, Allen MS, Grab JD, Gaissert HA, Harpole DH, Wright CD. Data from The Society of Thoracic Surgeons General Thoracic Surgery database: the surgical management of primary lung tumors. J Thorac Cardiovasc Surg. 2008 Feb;135(2):247-54.

34. Postmus PE. Epidemiology of lung cancer. In: Fishman AP; ed. Fishman's Pulmonary Diseases and Disorders. Third Edition. NewYork: McGraw-Hill Company; 1998:1707-17.

35. Utkaner G, Yılmaz U, Çelikten E, et al. Primer akciğer kanserli 116 olgunun analizi. Solunum Hastalıkları 1996;7:1-9.

36. Ginsberg RJ, Kris MG, Armstrong JG. Cancer of the Lung. In:DeVita VT, Hellman S, Rosenberg SA; eds. Cancer: Principles and Practice of Oncology. 4nd edition. Philedelphia: J.B. Lippincott Co; 1993:673-58.

37. Parkin DM, Sankaranarayanan R. Overview on small cell lung cancer in the world: Industrialized Countries, Third World, Eastern Europe. Anticancer Research 1994;14:277-82.
38. Altıay G, Tabakoğlu E, Çağlar T. 1993-1994 yılları arasında Trakya Üniversitesi Tıp Fakültesi'nde saptanan bronş kanserli hastaların değerlendirilmesi. Heybeliada Tıp Bülteni 1995;1:29-03.

39. Janssen-Heijnen MLG, Nab HW, van Reek J. Striking changes in smoking behaviour and lung cancer incidince by histological type in south-east Netherlands, 1960-1991. Eur J Cancer 1995;31:949-52.

40. Russo A, Crosignani P, Franceschi S, et al. Changes in lung cancer histological types in Varese cancer registry, Italy 1976-1992. Eur J Cancer 1997;33:1643-7.

41. Yaman M, Erturan S, YılmazZ Z. Kliniğimizin 44 yıllık akciğer kanseri hücre tipi sonuçları. In: Yaman M, Akkoçlu A, Kılınç G, Öztürk C, eds. Uluslararası akciğer kanseri ve bronkoskopi sempozyumu; 29 August - 01 September 2001; İstanbul, Turkey. 2001:SB-16.

42. Demir A, Turna A, Kocaturk C, et al. Prognostic significance of surgical-pathologic $\mathrm{N} 1$ lymph node involvement in non-small cell lung cancer. Ann Thorac Surg. 2009 Apr;87(4):1014-22.

43. Marra A, Hillejan L, Zaboura G, et al. Pathologic N1 non-small cell lung cancer: correlation between pattern of lymphatic spread and prognosis. J Thorac Cardiovasc Surg. 2003 Mar;125(3):543-53.

44. Yang H, Yao F, Zhao $Y$, et al. Clinical outcomes of surgery after induction treatment in patients with pathologically proven N2-positive stage III non-small cell lung cancer. J Thorac Dis 2015;7(9):1616-23.

45. Choi JH, Chung HC, Yoo NC. Changing trends in histologic types of lung cancer during the last decade (1981-1990) in Korea: a hospital-based study. Lung Cancer 1994;10:287-96. 